\title{
A Giant Left Atrial Hydatid Cyst in a Patient Presenting with Sudden-Onset Breathlessness
}

\author{
Ani Nefes Darlıg̃ı ile Bașvuran Hastada Dev Sol Atriyal Hidatik Kist
}

Enes Gül', Orhan Özbek², Mehmet Kayrak', Hasan Esen³, Turgut Teke ${ }^{4}$

'Department of Cardiology, Meram Faculty of Medicine, Selçuk University, Konya, Turkey 2Department of Radiology, Meram Faculty of Medicine, Selçuk University, Konya, Turkey ${ }^{3}$ Department of Pathology, Meram Faculty of Medicine, Selçuk University, Konya, Turkey

${ }^{4}$ Department of Pulmonary Disease, Meram Faculty of Medicine, Selçuk University, Konya, Turkey

\section{ABSTRACT}

Hydatid cysts rarely involve cardiac cavities and are mostly seen in the right chambers of the heart. The location of hydatid cysts in the left chambers of the heart is very harmful in terms of cerebrovascular risk. Herein, we report a case of a left atrial hydatid cyst which coexisted with a hydatid cyst in the liver. The patient was successfully operated on and discharged from the hospital on the fifth day after admission.

Keywords: Hydatid cyst, echocardiography Received: 11.05.2011 Accepted: 20.09.2011

\section{ÖZET}

Hidatik kistler nadien kalp boșluklarını tutabilir ve daha çok sag̃ kalp boșıklarında görülebilir. Hidatik kistlerin kalbin sol boșluklarını tutması serebrovasküler olay riski açısından çok tehlikelidir. Bu vakada biz karacig̃er hidatik kistine eșlik eden sol atriyal hidatik kist vakasını sunduk. Hasta bașarıyla ameliyat edildi ve hastaneye bașvurunun 5. gününde salahla taburcu edildi.

Anahtar Kelimeler: Hidatik kist, ekokardiyografi Geliş Tarihi: 11.05.2011 Kabul Tarihi: 20.09.2011

\section{Introduction}

Primary echinococcosis of the heart is exceptionally uncommon and is reported $0.5 \%$ to $2 \%$ in comparison with liver (70\%) or lung (20\%) involvement. Hydatid cysts are mostly seen in the right chambers of the heart. Hydatid cysts of the heart may remain asymptomatic. The clinical picture may vary from asymptomatic to congestive heart failure or drastic complications. The location of hydatid cysts in the left chambers of the heart is very harmful in terms of cerebrovascular risk.

\section{Case Report}

A 56-year-old man was admitted to the emergency department due to severe breathlessness. Upon physical examination, the patient appeared to be in moderate to severe respiratory distress. Auscultation of the heart revealed loud S1, diastolic murmur and presystolic accentuation pointing to signs of mitral stenosis. His heart rate was 118 beats per minute and regular; his blood pressure was 100/60 $\mathrm{mmHg}$. His respiratory rate was 38 breaths per minute, with an oxygen saturation of $88 \%$ while breathing ambient air. Laboratory parameters were within normal limits. Additionally, echocardiography was performed which showed a large mass in the left atrium. Transesophageal echocardiography revealed a giant mass filling the left atrium (Figure 1A). Computed tomography also confirmed the presence of a left atrial mass, and a large hydatid cyst that occupied the left lobe of the liver was also found (Figure 1B and 2). The patient was referred to surgery and post-operative material was sent to pathology. Microscopically, it consisted of eosinophilic lamellar material and was considered to be a hydatid cyst (Figure 3A and B). Medical treatment with albendasole $400 \mathrm{mg}$ per day was immediately initiated after surgical removal of the hydatid cyst.

\section{Discussion}

Cardiac presentation of hydatid cysts is rare as these cysts are mostly seen in the right chambers of the heart (1); pericardial, coronary sinus and left atrial involvement is very rare (2). The location of hydatid cysts in the left chambers of the heart is of ut- 

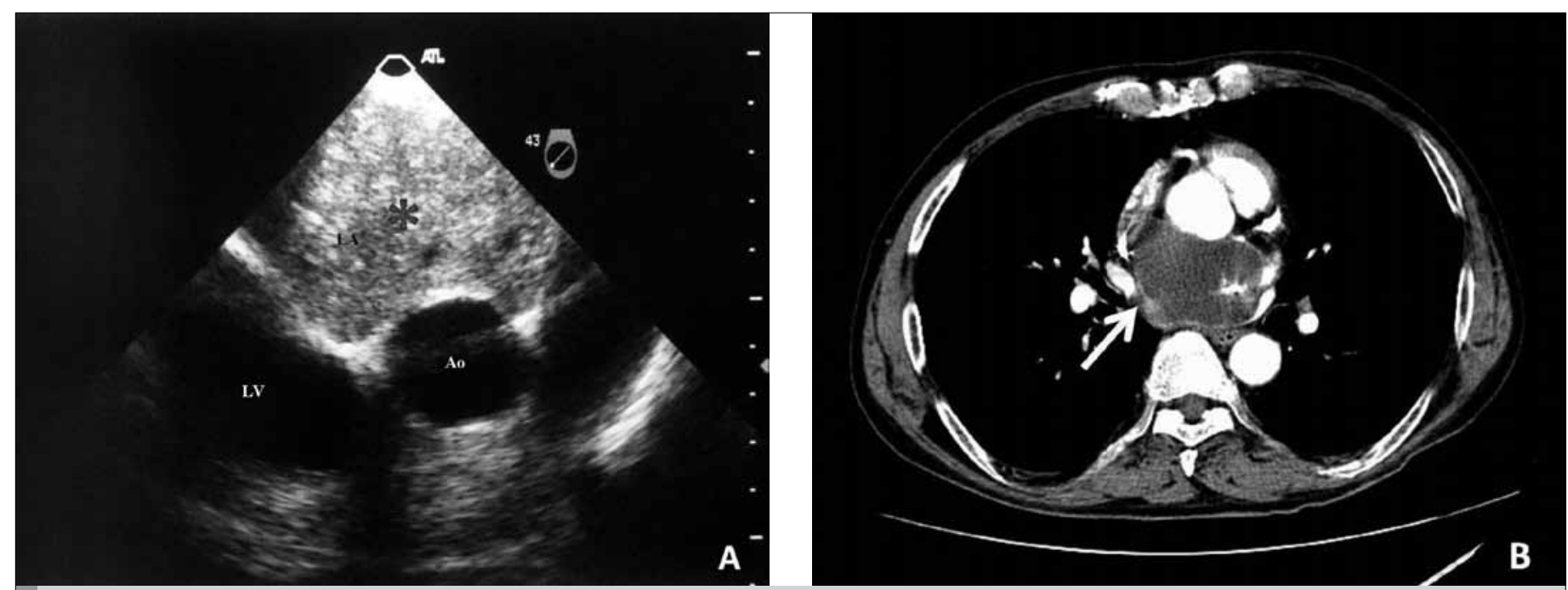

Figure 1. A) Transesophageal echocardiography showing a giant left atrial mass (asterisk); LV, left ventricle; LA, left atrium; Ao, aorta, B) Axial spiral CT section showing a cystic mass occupying the left atrium (arrow)

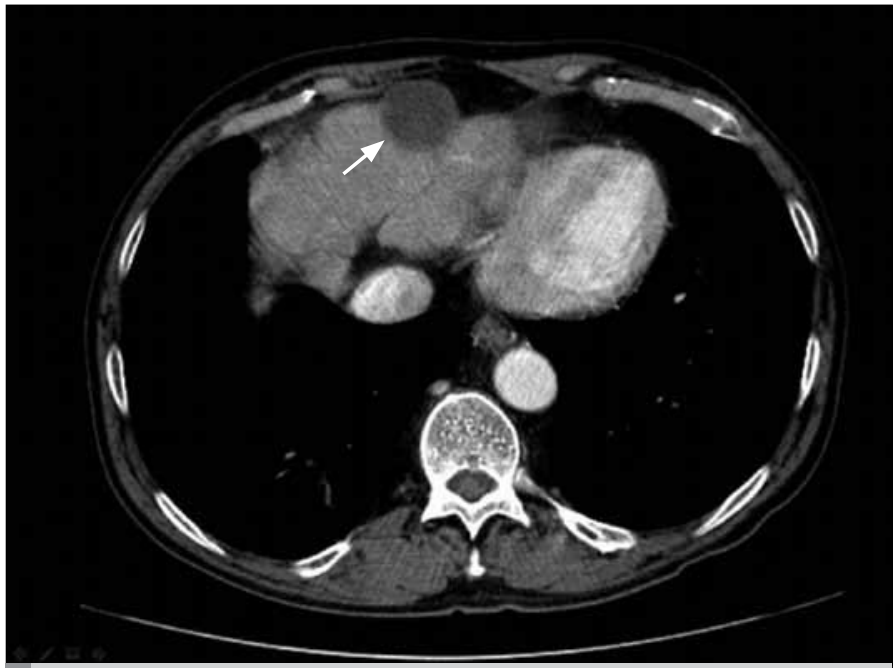

Figure 2. Computed tomography sections of the liver revealing a hydatid cyst occupying the left lobe of the liver (arrow)

most importance because of the risk of cerebrovascular events and pulmonary edema. There is a report in the literature that presents stroke as a cause of cardiac hydatidosis (3). In our patient, the cardiac cyst originated in the left atrium and did not involve the mitral valve orifice area. Sometimes, left atrial myxomas may mimic a hydatid cyst or vice versa $(4,5)$. To the best of our knowledge, multi-organ involvement including the liver and left atrium simultaneously has not been described before.

\section{Conclusion}

Cardiologists should keep in mind that the diagnosis of echinococcosis must be considered in patients with a giant cardiac mass and other accompanying hydatid cysts need to be investigated.

\section{Conflict of interest}

No conflict of interest was declared by the authors.

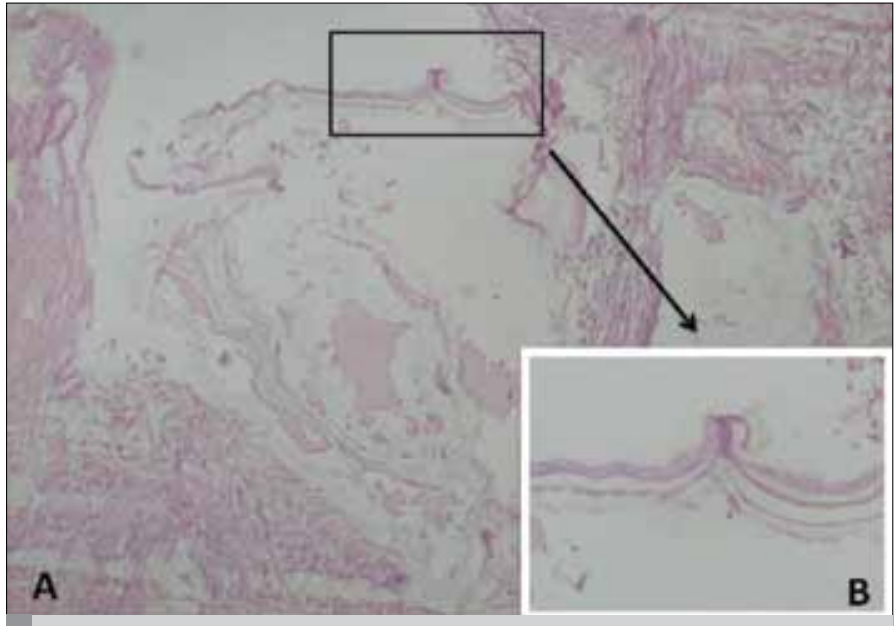

Figure 3. A) Optical microscopic evaluation exhibiting an acellular eosinophilic lamellar material in the fibrin thrombus mass (hematoxylineosin (HE) staining, magnification 40X); B) HE staining, 200X

\section{References}

1. Dighiero J, Canabal EJ, Aguirre CV, Hazan J, Horjales JO. Echinococcus disease of the heart. Circulation 1958; 17: 127-32. [CrossRef]

2. Birincioglu CL, Bardakci H, Kucuker SA, Ulus AT, Arda K, Yamak B, et al. A clinical dilemma: cardiac and pericardiac echinococcosis. Ann Thorac Surg 1999; 68: 1290-4. [CrossRef]

3. Singh NP, Arora SK, Gupta A, Anuradha S, Sridhara G, Agarwal SK, et al. Stroke: a rare presentation of cardiac hydatidosis. Neurol India 2003; 51: 120-1.

4. Ibanez B, Marcos-Alberca P, Rey M, de Rabago R, Orejas M, Renedo G, et al. Multicavitated left atrial myxoma mimicking a hydatid cyst. Eur J Echocardiogr 2005; 6: 231-3. [CrossRef]

5. Biyik I, Acar S, Ergene O. Left atrial mobile hydatid cyst mimicking left atrial myxoma and mitral stenosis and causing heart failure and arrhythmia. Int J Cardiovasc Imaging 2007; 23: 193-5. [CrossRef] 